\title{
Regulation of Intracellular Calcium by Carbon Monoxide in Human Bronchial Epithelial Cells
}

\author{
Rui-Gang Zhang Chung-Yin Yip Wing-Hung Ko \\ School of Biomedical Sciences, The Chinese University of Hong Kong, N.T., Hong Kong, China
}

\section{Key Words}

Carbon monoxide • Airway epithelia $•$ Purinergic receptor $•$ Calcium signaling $\cdot$ Store-operated calcium entry $\cdot$ Soluble guanylyl cyclase

\begin{abstract}
Background/Aims: Carbon monoxide (CO) is an important autocrine/paracrine messenger involved in a variety of physiological and pathological processes. This study aimed to investigate the regulatory role of $\mathrm{CO}$ released by CO-releasing molecule-2 (CORM-2) in a P2Y receptormediated calcium-signaling pathway in the human bronchial epithelial cell line, 16HBE140-. Methods: Intracellular calcium $\left(\left[\mathrm{Ca}^{2+}\right]_{\mathrm{i}}\right)$ was measured by fura- 2 microspectrofluorimetry. D-myo-inositol-1-phosphate $\left(\mathrm{IP}_{1}\right)$ levels and cGMP-dependent protein kinase activity (PKG) were also quantified. Results: The exogenous application of CORM-2 increased both intracellular $\mathrm{Ca}^{2+}$ and $\mathrm{IP}_{1}$, which are inhibited by U73122, a phospholipase $\mathrm{C}$ (PLC) inhibitor. In contrast, the $\mathrm{P}_{2} \mathrm{Y}_{2} / \mathrm{P}_{2} \mathrm{Y}_{4}$ receptor-mediated intracellular $\mathrm{Ca}^{2+}$ release and influx induced by UTP were inhibited in the presence of CORM-2. However, CORM-2 did not affect the storeoperated $\mathrm{Ca}^{2+}$ entry (SOCE) induced by thapsigargin (Tg). Moreover, the inhibitory effect of CORM-2 on UTP-induced calcium increase could be attenuated by a soluble guanylyl cyclase (sGC) inhibitor, $1 \mathrm{H}$-[1,2,4] oxadiazolo[4,3,-a]quinoxalin-1-one (ODQ), or a Protein Kinase G (PKG) inhibitor, KT5823, suggesting the involvement of sGC/PKG signaling in this process. Conclusion: CORM-2 serves a dual role in modulating $\left[\mathrm{Ca}^{2+}\right]_{i}$ in $16 \mathrm{HBE} 14 \mathrm{o}-$ cells. Thus, CO released by CORM-2 may act as a regulator of calcium homeostasis in human airway epithelia. These findings help further elucidate the function of $\mathrm{CO}$ in many physiological and pathological conditions.
\end{abstract}

\section{Introduction}

Carbon monoxide (CO) is a potent gas molecule with a variety of physiological functions, including vasodilation, anti-inflammation, anti-oxidative stress, and neuromodulation [1]. CO is produced endogenously by the heme oxygenase (HO) enzymes HO-1, HO-2, and HO-3. HO-2 and HO-3 (only expressed in rats) are constitutively expressed, whereas HO- 1 is induced by a wide range of stimuli $[2,3]$. Both $\mathrm{HO}-1$ and $\mathrm{HO}-2$ are reportedly expressed in human airway 
epithelial cells [4]. The measurement of the rate of endogenous CO production in humans using blood carboxyhemoglobin ( $\mathrm{CO}-\mathrm{Hb}$ ) analyses was first described by Coburn et al. and was found to be $\sim 0.42 \mathrm{ml} / \mathrm{hr}$ [5]. Endogenously produced $\mathrm{CO}$ is sufficient to maintain a CO$\mathrm{Hb}$ saturation level of $0.4-0.96 \%$ [6]. This $\mathrm{CO}-\mathrm{Hb}$ level can be elevated to $5 \%$ or even higher in heavy smokers [7]. Although it has been demonstrated that $\mathrm{CO}$ is a potential therapeutic agent in different animal models of inflammatory disease $[8,9]$, increasing the $\mathrm{CO}-\mathrm{Hb}$ level to $7 \%$ by $\mathrm{CO}$ inhalation had no anti-inflammatory effects in a systemic lipopolysaccharideinduced inflammation model in humans [10]. Therefore, further clinical experiments are required to investigate the safety and efficacy of $\mathrm{CO}$ inhalation as a treatment for human inflammatory lung diseases.

To provide safe and controlled delivery of $\mathrm{CO}$ into cells, CO-releasing molecules (CORMs) have been developed and tested over the past decade [11]. CORM-2, a lipidsoluble metal carbonyl complex tricarbonyl dichlororuthenium (II) dimer $\left(\left[\mathrm{Ru}(\mathrm{CO})_{3} \mathrm{Cl}_{2}\right]_{2}\right)$, is commonly used experimentally to release $\mathrm{CO}$ and to elicit various biological activities such as a vasodilatory effect on rat aortic rings [12], an anti-inflammatory effect in murine macrophages $[13,14]$, and an anti-bacterial effect [15]. By measuring the conversion of deoxymyoglobin to carbonmonoxy myoglobin spectrophotometrically, it has been estimated that for each mole of CORM-2, approximately 0.7 moles of $\mathrm{CO}$ are rapidly released with a half-life of about 20 minutes [12].

P2Y receptors are expressed in virtually all epithelia, where they are activated by extracellular nucleotides such as ATP and UTP [16] and control the transport of fluid and electrolytes. Eight P2Y receptor subtypes have been defined. We previously reported four subtypes of $\mathrm{P} 2 \mathrm{Y}$ receptors ( $\mathrm{P}_{2} \mathrm{Y}_{1}, \mathrm{P}_{2} \mathrm{Y}_{2}, \mathrm{P}_{2} \mathrm{Y}_{4}$, and $\left.\mathrm{P} 2 \mathrm{Y}_{6}\right)$ expressed in human bronchial epithelial cell line 16HBE14o-. 16HBE14o- cells are an immortalized cell line that was derived from the human bronchial surface epithelium [17]. These cells represent a good model for investigating transepithelial $\mathrm{Cl}^{-}$secretion [18, 19], airway inflammation, and airway remodeling [20-22]. Our previous studies showed that activation of P2Y receptors regulated epithelial $\mathrm{Cl}^{-}$secretion via both $\mathrm{Ca}^{2+}$ - and cAMP-dependent pathways [23] and activated the PLC- D-myo-inositol 1, 4,5-triphosphate $\left(\mathrm{IP}_{3}\right)-\mathrm{Ca}^{2+}$ signaling cascade in $16 \mathrm{HBE} 14 \mathrm{o}-$ cells, which is also responsible for the secretion of at least two pro-inflammatory cytokines, interleukin (IL)- 6 and IL-8, when the cells were challenged by cationic proteins [24]. Therefore, we sought to test whether $\mathrm{CO}$ would modulate the P2Y receptor-mediated calcium-signaling pathway.

Calcium ions $\left(\mathrm{Ca}^{2+}\right)$ impact nearly every aspect of life; therefore, calcium signaling and $\mathrm{Ca}^{2+}$ levels are highly controlled [25]. Intracellular $\mathrm{Ca}^{2+}$ may come from either calcium release from intracellular $\mathrm{Ca}^{2+}$ stores, such as the endoplasmic reticulum (ER), and/or $\mathrm{Ca}^{2+}$ influx. In electrically non-excitable cells, the major $\mathrm{Ca}^{2+}$ entry pathway is reported to be storeoperated calcium entry (SOCE) [26]. However, there is substantial evidence that a non-storeoperated calcium entry pathway, known as receptor-operated calcium entry (ROCE), may exist. Although ROCE is well studied in excitable cells, it also exists in non-excitable cells [27, 28]. Therefore, it is possible that the activation of $\mathrm{P} 2 \mathrm{Y}$ receptors could activate both SOCE and ROCE in human bronchial epithelia; thus, it would be interesting to test if CORM-2 has any effect on SOCE and/or ROCE. Although some reports suggest that CO maybe a regulator of ion channels [29], and that CO can inhibit T-type calcium channels in neuronal cells [30] and affect calcium signaling in pancreatic acinar cells [31], the regulatory effects of CO on intracellular calcium in human airway epithelia remain largely unknown. To our knowledge, this is the first study to examine the effect of CO released by CORM-2 on $\mathrm{Ca}^{2+}$ signaling and its interaction with the purinergic signaling pathway in human bronchial epithelial cells.

\section{Materials and Methods}

Cell culture

16HBE140- cells were maintained in Minimum Essential Medium with Earle's salt supplemented with $10 \%$ (vol/vol) fetal bovine serum, 1\% (vol/vol) L-glutamine, $100 \mathrm{IU} / \mathrm{ml}$ penicillin, and $100 \mu \mathrm{g} / \mathrm{ml}$ 
streptomycin, as previously described [23]. Cells were cultured in plastic flasks coated with fibronectin and collagen (BD Biosciences, San Jose, CA, USA) and were incubated in humidified $5 \% \mathrm{CO}_{2}$ air at $37^{\circ} \mathrm{C}$. For the $\mathrm{IP}_{1}$ assay, cells were seeded in a 96-well plate at the density of $2 \times 10^{4} /$ well. For calcium measurement, cells were seeded in a standard culture dish $(35 \mathrm{~mm})$ with a coverslip.

\section{Calcium measurement}

Cells were incubated with fura- $2 \mathrm{AM}(3 \mu \mathrm{M})$ and pluronic F127 $(1.6 \mu \mathrm{M})$ for $40 \mathrm{~min}$ at $37^{\circ} \mathrm{C}$. Cells were then washed with Krebs-Henseleit $(\mathrm{KH})$ solution and the coverslip was transferred to a closed perfusion chamber and mounted on the stage of an inverted microscope (Nikon ECLIPSE TE300, Japan) coupled to the PTI Ratio-Master fluorescence system (Photon Technology International, NJ, USA). The fluorescence intensity ratio (excitation at $340 / 380 \mathrm{~nm}$; emission $>510 \mathrm{~nm}$ ) was collected. The data are shown quantitatively as a change in the Fura-2 fluorescence ratio $(340 / 380 \mathrm{~nm})$. The $\mathrm{KH}$ solution contained $117 \mathrm{mM} \mathrm{NaCl}, 25 \mathrm{mM}$ $\mathrm{NaHCO}_{3}, 4.7 \mathrm{mM} \mathrm{KCl}, 1.2 \mathrm{mM} \mathrm{MgSO}_{4}, 1.2 \mathrm{mM} \mathrm{KH}_{2} \mathrm{PO}_{4}, 2.5 \mathrm{mM} \mathrm{CaCl}_{2}$, and $11 \mathrm{mM}$ D-glucose, $\mathrm{pH}$ 7.4, when mixed with $5 \% \mathrm{CO}_{2}$ and $95 \% \mathrm{O}_{2}$. The composition of the nominally $\mathrm{Ca}^{2+}$-free $\mathrm{KH}$ was the same as normal $\mathrm{KH}$ with the exception that there was no $\mathrm{CaCl}_{2}$ in the solution.

IP ${ }_{1}$ assay

Because the lifetime of IP ${ }_{3}$ within the cell is very short before it is transformed into $\mathrm{IP}_{2}$ and $\mathrm{IP}_{1}, \mathrm{IP}_{1}$ accumulation levels can be used to represent $\mathrm{IP}_{3}$ levels in cells [32]. The $\mathrm{IP}_{1}$ measurements were performed as recently described [32]. Agonist-induced IP ${ }_{1}$ in LiCl-treated cells was quantified using the Cisbio IP-One kit (Cisbio Bioassays, Codolet, France) per the manufacturer's instructions. Light emitted at 615 and $665 \mathrm{~nm}$ was measured on a Spectra Max i3X Multimode Plate Reader (Molecular Devices, CA, USA) using the HTRF mode after excitation at $340 \mathrm{~nm}$. The FRET ratios $(665 \mathrm{~nm} / 615 \mathrm{~nm})$ were converted to concentrations of IP $_{1}$ using the provided standard.

\section{PKG activity assay}

Cells were grown in $35 \mathrm{~mm}$ cell culture dishes (SPL Life sciences Co. Ltd, Korea). Cells were incubated in serum-free medium overnight after they reached confluence. Cells were then treated with either CORM-2 or $\mathrm{RuCl}_{3}$, the negative control for CORM-2, for $15 \mathrm{~min}$. KT5823 was applied 10 min before CORM-2 treatment. Protein was extracted using standard methods. Protein $(50 \mu \mathrm{g})$ was added to each well for further assay. The PKG activity assay was performed using the Cylex cyclic GMP-dependent protein kinase assay kit (MBL, USA) as previously described [33].

\section{Materials}

All chemicals were acquired from Sigma-Aldrich (St. Louis, MO, USA), and all cell culture reagents were obtained from Invitrogen (Carlsbad, CA, USA).

\section{Data analyses}

Data are presented as mean \pm standard error (S.E.) and the values of $n$ refer to the number of experiments in each group. Statistical comparisons were performed using either a Student's t-test or oneway ANOVA (followed by post hoc tests). A $p<0.05$ was considered significant.

\section{Results}

CORM-2 caused an increase in $\left[\mathrm{Ca}^{2+}\right]_{i}$

Fig. $1 A$ shows the effect of different concentrations of CORM- 2 on the increase in $\left[\mathrm{Ca}^{2+}\right]_{\mathrm{i}}$ as monitored by the Fura-2 fluorescence ratio. CORM-2 was applied to the perfusate at time $0 \mathrm{~min}$ and was present throughout the entire experimental period. The application of CORM2 to the $16 \mathrm{HBE} 14 \mathrm{o}$ - cells in the $\mathrm{Ca}^{2+}$-containing $\mathrm{KH}$ solution induced a slow increase in $\left[\mathrm{Ca}^{2+}\right]_{\mathrm{i}}$ Increasing the concentration of CORM-2 caused a larger increase in $\left[\mathrm{Ca}^{2+}\right]_{\mathrm{i}}$ and shortened the time to reach peak $\left[\mathrm{Ca}^{2+}\right]_{\mathrm{i}}$. The maximum increase in $\left[\mathrm{Ca}^{2+}\right]_{\mathrm{i}}$ was concentration-dependent, with an $\mathrm{EC}_{50}$ of $52.7 \pm 0.5 \mu \mathrm{M}$ as shown in Fig. $1 B$. The inactive form of CORM-2, iCORM-2 (100 $\mu \mathrm{M}$ ), had no significant effect (Fig. $1 C$ ). A slight increase in $\left[\mathrm{Ca}^{2+}\right]_{i}$ was observed when the cells 
Fig. 1. Characteristics of calcium increase induced by CORM-2. (A) 16HBE14o- cells were exposed to different concentrations of CORM-2 in Normal $\mathrm{KH}$ at time 0 min and the maximal increase in the Fura-2 fluorescence ratio was quantified. Similar results were obtained for at least three replicates. (B) Concentration-response curve for the change in the Fura2 to CORM-2 ratio. (C) 16HBE14o- cells were stimulated at time 0 min with (i) CORM-2 (100 $\mu \mathrm{M})$ in Normal $\mathrm{KH}$ or nominally $\mathrm{Ca}^{2+}$-free solution; (ii) inactive CORM-2 (iCORM-2) $(100 \mu \mathrm{M})$ in Normal $\mathrm{KH}$ solution; and (iii) CORM-2 (100 $\mu \mathrm{M})$ and $\mathrm{U} 73122(10 \mu \mathrm{M})$ in Normal KH solution. Similar results

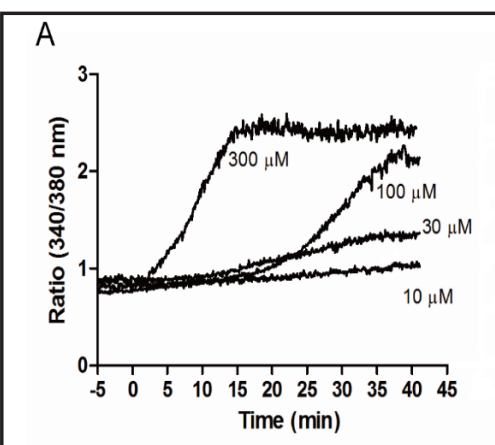

C

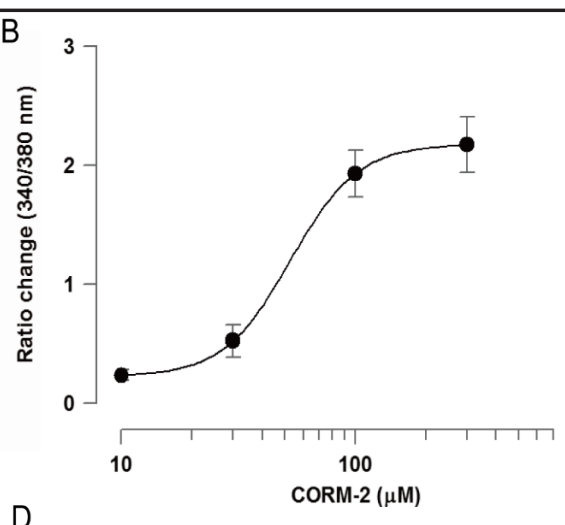

- CORM-2 (100 HM)

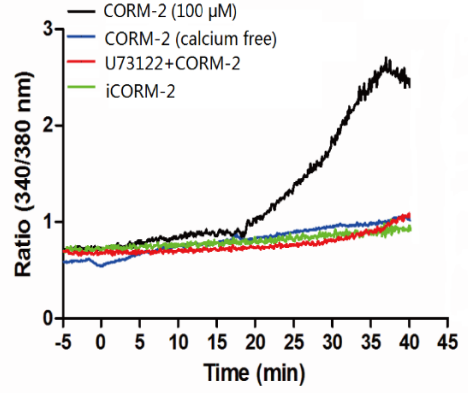

E

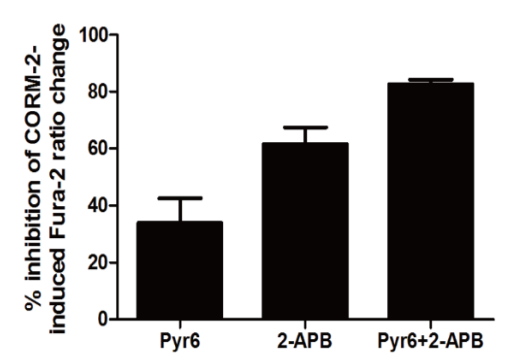

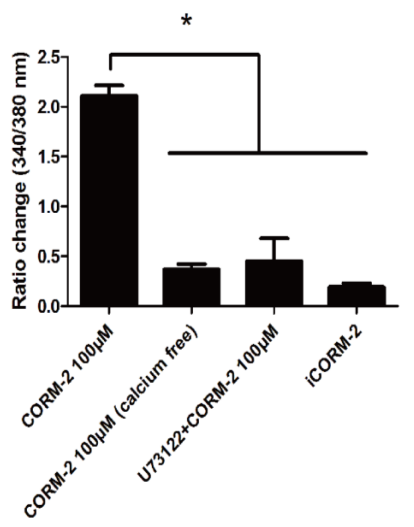
were obtained for at least four replicates. (D) Statistical results for (C). Each column represents the mean \pm S.E. $(n=4) ;{ }^{*}<<0.05$, one-way ANOVA with Dunnett's post hoc test. (E) 16HBE14o- cells were superfused with normal KH solution and then stimulated with CORM-2 and treated with Pyr-6 $(10 \mu \mathrm{M}), 2-\mathrm{APB}(10 \mu \mathrm{M})$,) or both after the CORM-2-induced calcium changes had reached peak levels. Inhibition was calculated as a percent relative to the maximal increase in the Fura-2 ratio induced by CORM-2 in the presence of Pyr-6, 2-APB, or both (n $=3-5)$.

were stimulated with $100 \mu \mathrm{M}$ CORM-2 in $\mathrm{Ca}^{2+}$-free $\mathrm{KH}$ solution (Fig. 1C). The summarized data are shown in Fig. $1 D$. The results indicated that the calcium increase induced by $100 \mu \mathrm{M}$ CORM-2 was mainly due to $\mathrm{Ca}^{2+}$ entry from the extracellular medium.

To test whether calcium entry induced by CORM-2 is mediated by the emptying of $\mathrm{Ca}^{2+}$ stores by the PLC-IP 3 signaling pathway, the cells were stimulated with CORM-2 $(100 \mu \mathrm{M})$ at time 0 min in the presence of the PLC inhibitor U73122 (Fig. 1C). In the presence of U73122 $(10 \mu \mathrm{M})$, the CORM-2-induced $\mathrm{Ca}^{2+}$ increase was almost completely abolished (CORM-2, change in ratio $=2.18 \pm 0.18 ;$ CORM- $+\mathrm{U} 73122$, change in ratio $=0.45 \pm 0.23 ; p<0.05, n=$ 4; Fig. 1D).

To study the involvement of different $\mathrm{Ca}^{2+}$ entry pathways in CORM-2-mediated calcium increase, two calcium entry blockers, N-[4-[3, 5-Bis(trifluoromethyl)-1H-pyrazol-1-yl] phenyl]-3-fluoro-4-pyridinecarboxamide (Pyr6) and 2-Aminoethoxydiphenyl borate (2- 
APB), were used. Pyr6 is a novel inhibitor of SOCE, which exhibited 37-fold higher inhibition of Orai1mediated $\mathrm{Ca}^{2+}$ entry versus TRPC3-mediated $\mathrm{Ca}^{2+}$ entry [34]. 2-APB is widely used as an inhibitor of voltageindependent $\mathrm{Ca}^{2+}$ entry including SOCE [35] and TRP channel-mediated calcium entry [36]. In addition, the $\mathrm{IP}_{3}$ receptormediated calcium release can also be suppressed by 2-APB [37]. Figure1E shows the percent inhibition of the CORM-2 induced Fura2 ratio by Pyr6 and 2-APB. The cells were stimulated with CORM-2 $(100 \mu \mathrm{M})$ and Pyr6 $(10 \mu \mathrm{M})$ and/or 2-APB $(10 \mu \mathrm{M})$ was added once the CORM-2-induced calcium levels had reached the maximum level. When Pyr6 $(10 \mu \mathrm{M})$ was added at the peak of the CORM-2induced $\mathrm{Ca}^{2+}$ increase, it suppressed $34.0 \% \pm 8.6 \%$ (before Pyr6, change in ratio $=2.06 \pm 0.20$, $n=5$; after Pyr6, change in ratio $=1.43 \pm 0.13, n=3$ ) of the maximal calcium response (Fig. $1 E$ ). However, 2-APB alone largely reduced the CORM-2-induced $\mathrm{Ca}^{2+}$ increase (after 2-APB, change in ratio $=0.78 \pm 0.07, n=5 ; \%$ inhibition $=61.6 \% \pm 6.0 \%$ ). The $\%$ inhibition increased to $82.7 \% \pm 1.6 \%$ (after Pyr $6+2-\mathrm{APB}$, change in ratio $=0.28 \pm 0.06, n=3$ ) when both Pyr6 and 2 -APB were present. Taken together, these results indicate that CORM-2- induced calcium signaling involves the activation of the $\mathrm{PLC} / \mathrm{IP}_{3}$ pathway and the involvement of the Pyr-6- or 2-APB- sensitive calcium entry pathway.

\section{CORM-2 induced $I P_{3}$ production}

Because the PLC inhibitor abolished the calcium increase induced by CORM-2, it is likely that CORM-2 could induce $\mathrm{IP}_{3}$ production via the $\mathrm{PLC} / \mathrm{IP}_{3}$ signaling cascade. To examine the activity of PLC, 16HBE14o- cells were stimulated with different concentrations of CORM-2 for $1 \mathrm{hr}$ and $\mathrm{IP}_{1}$, a non-degradable stable product of $\mathrm{IP}_{3}$, was measured. Our results indicated that CORM-2 induced $\mathrm{IP}_{1}$ formation in a concentration-dependent manner with an $\mathrm{EC}_{50}$ of $9.98 \mu \mathrm{M}$ (Fig. $2 A$ ). For the positive control experiment, activation of $\mathrm{P}_{2} \mathrm{Y}_{2} / \mathrm{P}_{2} \mathrm{Y}_{4}$ receptor by UTP caused an increase in IP ${ }_{1}$ formation, which could be inhibited by U73122 (Fig. 2B). Similarly, U73122 abolished IP accumulation induced by CORM-2 (Fig. $2 B$ ), indicating that CORM-2 could activate the PLC/ $\mathrm{IP}_{3}$ signaling cascade. iCORM-2 has no significant effect on $\mathrm{IP}_{1}$ formation.

\section{CORM-2 suppressed UTP-induced calcium increase}

To test whether CORM-2 has an effect on G protein-coupled receptor-mediated $\mathrm{Ca}^{2+}$ signaling, the cells were stimulated with UTP $\left(a \mathrm{P} 2 \mathrm{Y}_{2} / \mathrm{P} 2 \mathrm{Y}_{4}\right.$ receptor agonist) in the absence or presence of $30 \mu \mathrm{M}$ CORM-2 (Fig. $3 A$ ). At this concentration, CORM-2 did not induce a significant increase in $\left[\mathrm{Ca}^{2+}\right]_{\mathrm{i}}$ as shown in Fig. $1 A$. CORM-2 suppressed the calcium increase induced by $5 \mu \mathrm{M}$ UTP in a concentration-dependent manner, with an $\mathrm{IC}_{50}$ of $11.45 \mu \mathrm{M}$ (Fig. $3 B$ ). We further studied whether CORM-2 inhibited the P2Y receptor-mediated calcium release and/or influx component in 16HBE14o- cells using an extracellular $\mathrm{Ca}^{2+}$ removal/readdition protocol as previously described [38]. The control experimental protocol involved stimulating the cells with UTP in a $\mathrm{Ca}^{2+}$-free solution to deplete the internal $\mathrm{Ca}^{2+}$ stores, after 
which $2.0 \mathrm{mM} \mathrm{Ca}^{2+}$ was added to the perfusion solution to detect the $\mathrm{Ca}^{2+}$ influx (Fig. 3C). In another series of experiments, the same protocol was applied but the cells were perfused with different concentrations of CORM-2, as indicated, to determine its effect on UTP-induced calcium release and influx component. These results demonstrate that both calcium release (Fig. 3D) and influx (Fig. 3E) could be inhibited by CORM-2 in a concentration-dependent manner with an $\mathrm{IC}_{50}$ of 9.39 and $7.75 \mu \mathrm{M}$, respectively.

\section{The inhibitory effect of CORM-2 on UTP-induced calcium influx was not due to the decreased} calcium release

Although it is clear that both the calcium release and influx induced by UTP were inhibited by CORM-2, it is possible that the suppressed calcium influx was due to impaired calcium release and retention of $\mathrm{Ca}^{2+}$ in calcium stores. Therefore, a similar protocol as described in Fig. $3 C$ was used, but CORM-2 was added after the UTP-induced calcium release from

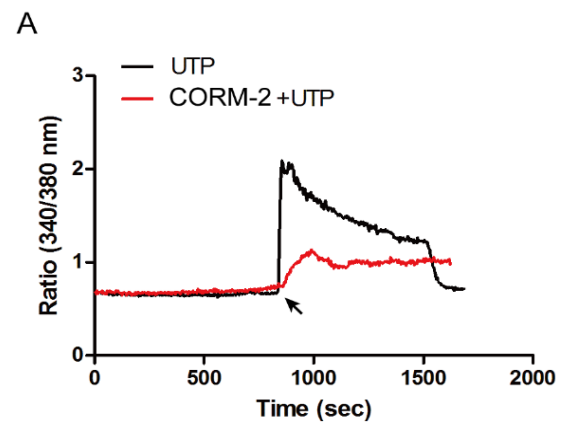

B

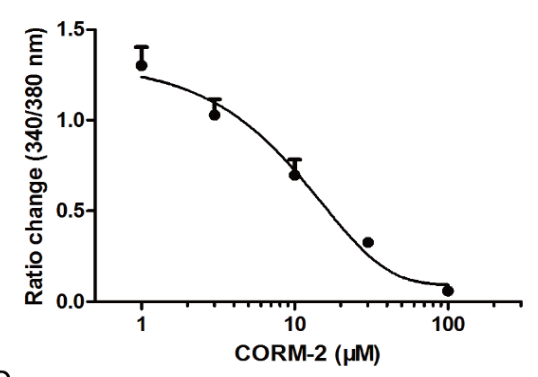

C

D
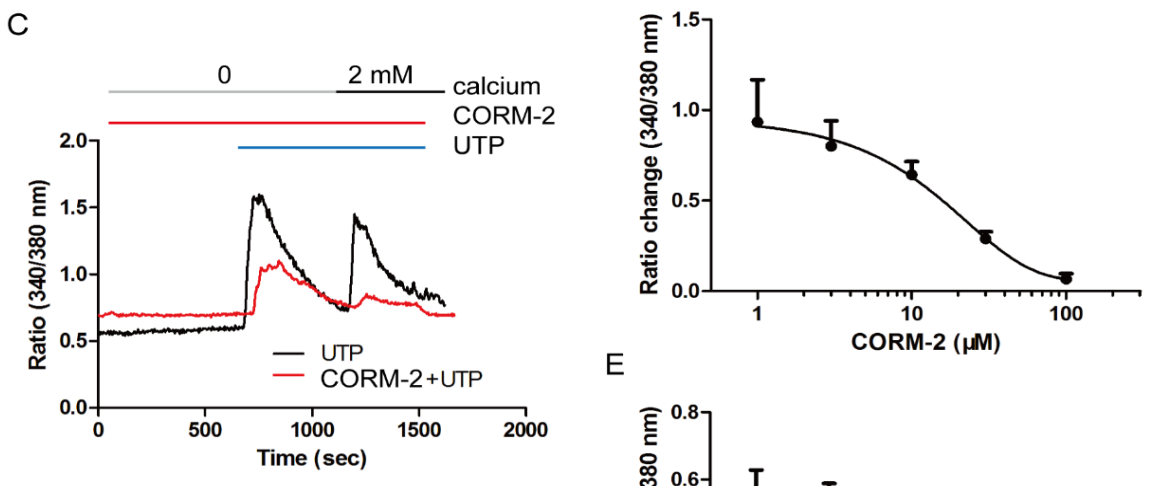

E

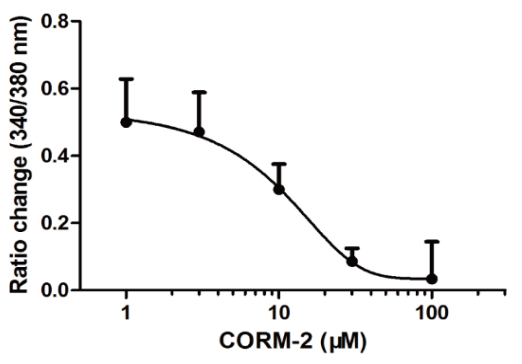

Fig. 3. CORM-2 suppressed UTP-induced calcium increase. (A) 16HBE14o- cells were stimulated with UTP $(5 \mu \mathrm{M})$ in the presence or absence of CORM-2 $(30 \mu \mathrm{M})$. The arrow indicates where UTP was added $(n=3-4)$. (B) Summarized data showing the UTP-induced increases in $\left[\mathrm{Ca}^{2+}\right]_{i}$ were inhibited by different concentrations of CORM-2. Each data point represents the mean \pm S.E. $(n=3-4)$. (C) Representative recordings of Fura-2 fluorescence ratios showing the calcium release and calcium influx induced by UTP in the absence or presence of CORM-2. 16HBE140- cells were superfused with nominally $\mathrm{Ca}^{2+}$-free $\mathrm{KH}$ solution and then stimulated with UTP. Once $\left[\mathrm{Ca}^{2+}\right]_{\mathrm{i}}$ returned to basal levels, external $\mathrm{Ca}^{2+}$ was subsequently restored $(2 \mathrm{mM})$ ( $n=5-7)$. Summarized data demonstrate CORM-2 concentration-dependently inhibited both calcium release (D) and calcium influx (E). Each data point represents the mean \pm S.E. for $5-7$ experiments. 


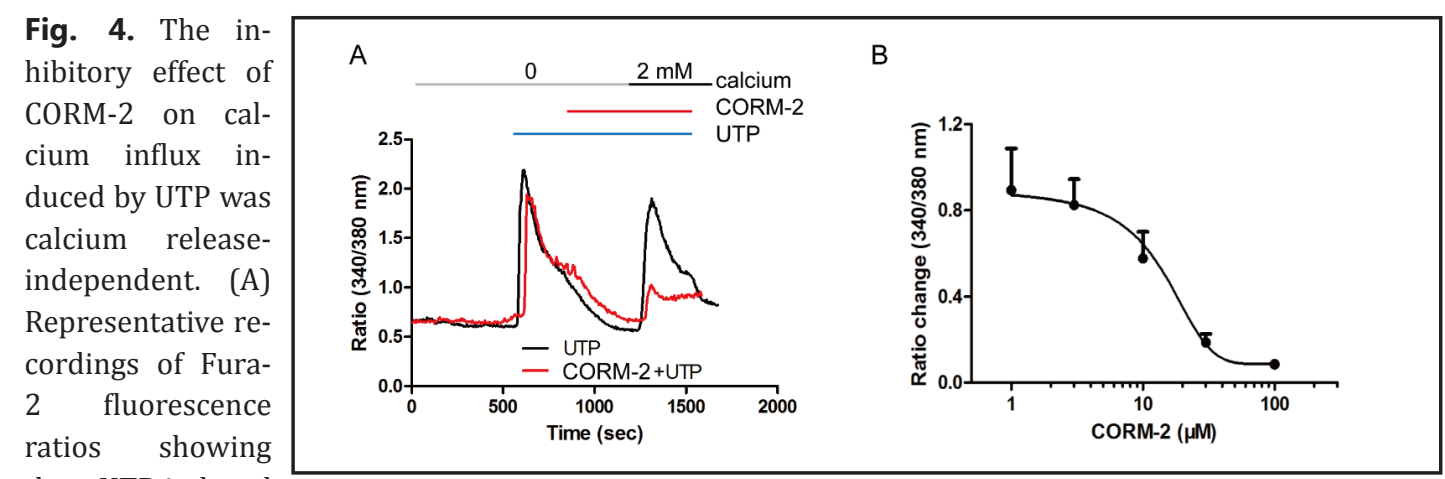
the UTP-induced

calcium influx in the absence or presence of CORM-2 $(30 \mu \mathrm{M}) . \mathrm{A} \mathrm{Ca}^{2+}$ removal/addition protocol similar to that described in Fig. 3. was used. However, CORM-2 was added after the UTP-induced $\mathrm{Ca}^{2+}$-release reached its peak $(n=4)$. (B) Summarized data showing the UTP-induced calcium influx was inhibited by different concentrations of CORM-2. Each data point represents the mean \pm S.E. $(n=4)$.

internal stores. Fig. $4 A$ shows that CORM-2 $(30 \mu \mathrm{M})$ was still capable of inhibiting calcium influx $(33.4 \% \pm 14.9 \%$ of control) despite no significant change in the calcium release component (control, change in ratio $=1.12 \pm 0.13$; CORM-2, change in ratio $=1.09 \pm 0.12$; p>0.05, $n=5$ ) upon UTP stimulation. In the absence of CORM-2 (control), the UTP-induced increase in the Fura- 2 ratio associated with the calcium influx was $1.09 \pm 0.16$. Fig. $4 B$ shows that this inhibitory effect of CORM-2 on the UTP-induced calcium influx was concentrationdependent with an $\mathrm{IC}_{50}$ of $12.41 \mu \mathrm{M}$ (Fig. $4 B$ ).

\section{CORM-2 had no inhibitory effect on SOCE}

SOCE is assumed to be a major ubiquitous pathway for calcium entry in non-excitable cells, such as epithelial cells [26]. Thapsigargin (Tg), a specific ER $\mathrm{Ca}^{2+}$-ATPase inhibitor [39], was used as a pharmacological tool to deplete the internal calcium store and to bypass the receptors and the subsequent signaling cascade to activate SOCE. In the absence of extracellular $\mathrm{Ca}^{2+}, \mathrm{Tg}(1 \mu \mathrm{M})$ induced the emptying of intracellular $\mathrm{Ca}^{2+}$ stores, and a calcium influx occurred upon restoring extracellular $\mathrm{Ca}^{2+}$ in the perfusate (Fig. $5 \mathrm{~A}$ and $\mathrm{C}$ ). We examined the effects of CORM-2 on SOCE by incubating the cells with CORM-2 throughout the entire experimental period (Fig. $5 A$ ) or after calcium stores had been depleted by $\mathrm{Tg}$ (Fig. 5C). CORM-2 did not affect calcium released by Tg (Fig. 5B). Calcium entry after store depletion was not significantly different between control and CORM-2-treated cells (Fig. $5 B$ and $D$ ) in either protocol. Together with previous data, these results suggest that the P2Y receptor-induced calcium entry pathway inhibited by CORM-2 is different from the SOCE activated by Tg.

\section{UTP-induced calcium influx was insensitive to SOCE inhibitor}

To distinguish between SOCE and UTP-induced ROCE, Pyr6 and 2-APB were used to differentiate the two different calcium influx pathways. The cells were stimulated with UTP in $\mathrm{Ca}^{2+}$-free solution to deplete the intracellular $\mathrm{Ca}^{2+}$ stores, followed by the addition of $\mathrm{Ca}^{2+}$ back into the perfusion solution in the continued presence of UTP. The non-specific calcium entry blocker, 2-APB, almost completely suppressed the P2Y receptor-mediated calcium entry (Fig. $6 A$, red trace) when compared to the control cells (black trace). The addition of 2 $\mathrm{mM}$ calcium to the perfusion solution induced only a minimal increase in calcium entry (control: change in ratio $=0.72 \pm 0.09, n=7 ;+2$-APB, change in ratio $=0.07 \pm 0.06, n=3, \mathrm{p}<0.05$; $\%$ inhibition $=90.8 \% \pm 6.1 \%$ ). In contrast, Fig. $6 B$ shows that the SOCE specific inhibitor, Pyr6, had no significant effect on the ROCE activated by UTP (+ Pyr6: change in ratio $=0.67 \pm$ $0.22, n=4, \mathrm{p}>0.05$ ). On the other hand, the SOCE activated by Tg was sensitive to both 2-APB (Fig. 6C) and Pyr 6 (Fig. 6D). The addition of 2-APB or Pyr6 to the cells when the Tg-induced calcium influx had reached a plateau caused a rapid decline in the Fura-2 ratio towards the 
Fig. 5. CORM-2 did not suppress the Tg-induced calcium release and influx. Representative recordings of Fura-2 fluorescence ratios showing the effect of CORM-2 (100 $\mu \mathrm{M})$, either treated before (A) or after (C) the cells were stimulated with $1 \mu \mathrm{M}$ Tg. Summarized data showing the effects of CORM-2 on Tg-induced calcium release and influx (B) or influx alone (D). Each column represents the mean \pm S.E. ( $\mathrm{n}=4-8$; Student's t-test with Welch's correction).

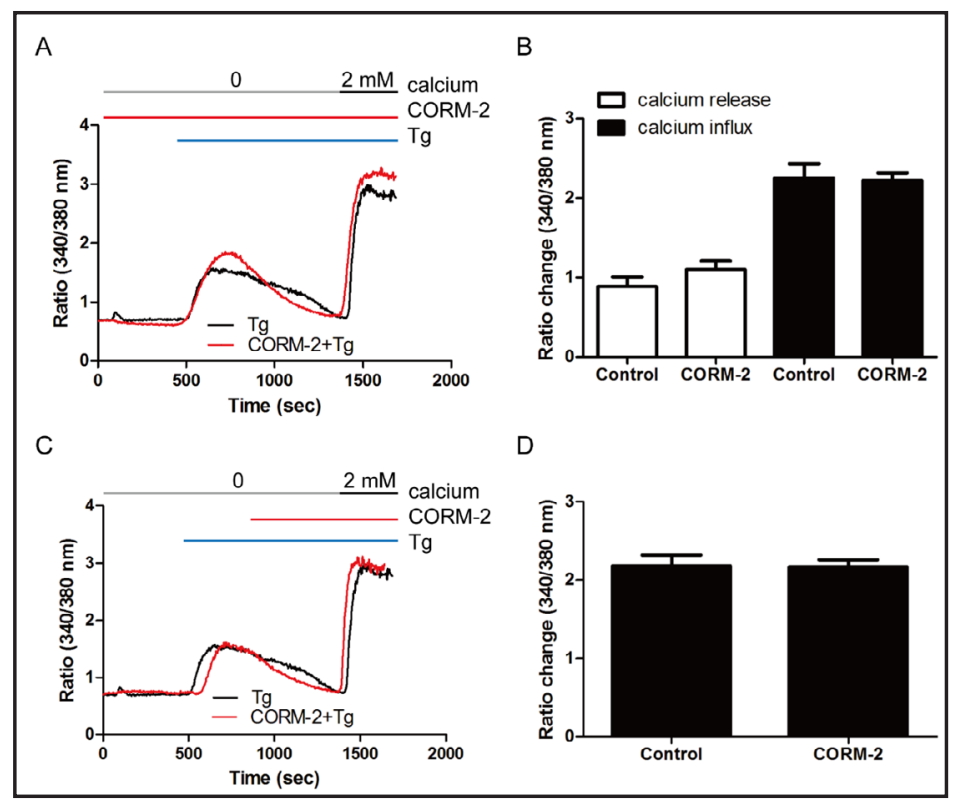

Fig. 6. Different sensitivity of the UTP- and Tg-induced calcium influx to Pyr6 and 2-APB. A $\mathrm{Ca}^{2+}$ removal/ addition protocol similar to that described in Fig. 3. was used. Representative recordings of Fura-2 fluorescence ratios showing the effects of 2-APB $(A, C)$ or Pyr6 (B, D) on UTP (A, B) or $\mathrm{Tg}$ (C, D)-induced calcium influx (red trace) versus control without the addition of Pyr6 or 2-APB (black trace). Similar results were obtained for at least three to eight replicates.

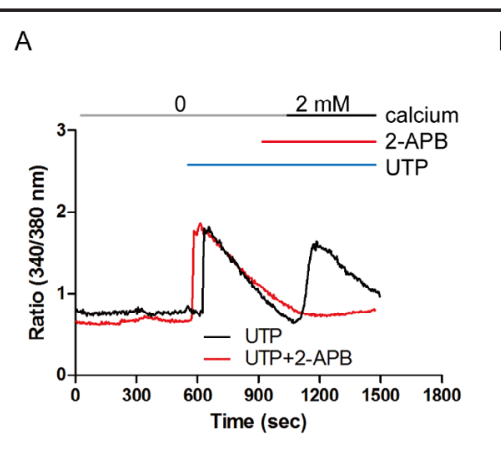

B
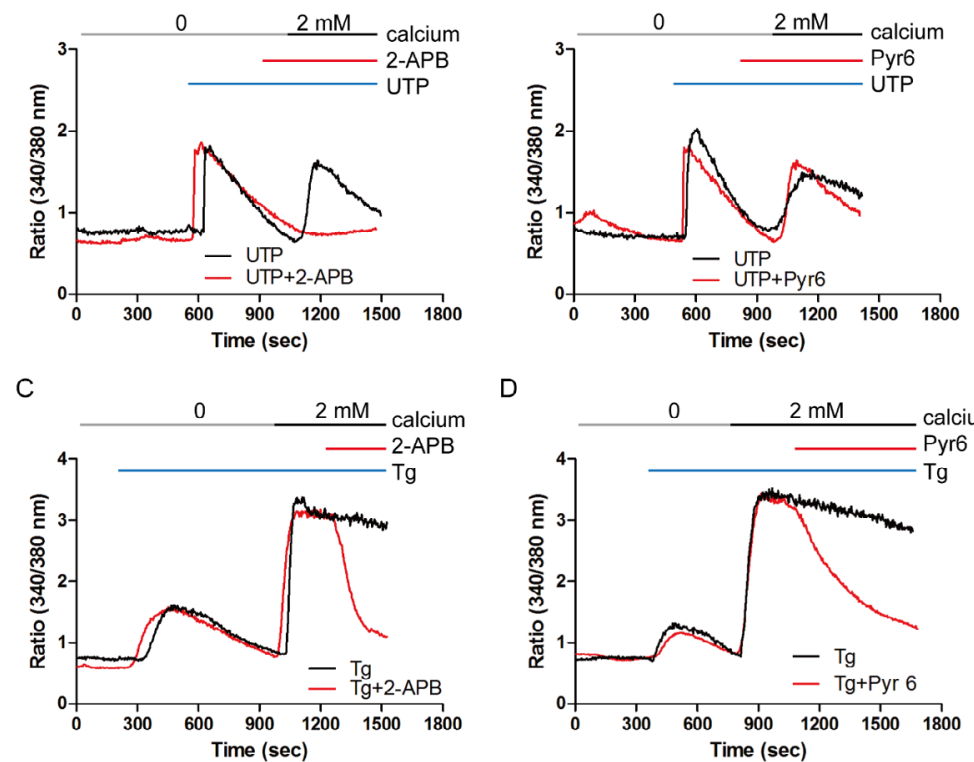

D

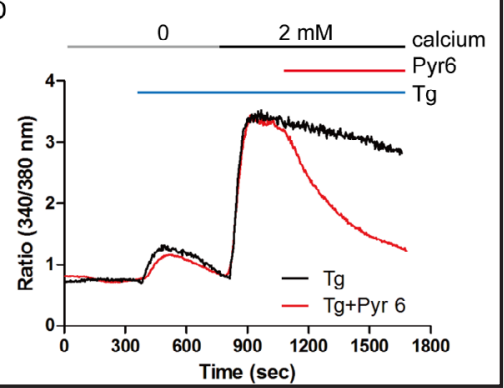

pre-stimulated level. When compared with the Fura-2 ratio at the same time point when the calcium levels in the control cells reached a steady level, the percent inhibition of 2-APB and Pyr6 on the Tg-induced calcium influx was $83.4 \% \pm 6.6 \%$ (control,: change in ratio $=2.41 \pm$ $0.05, n=8$; + 2-APB, change in ratio $=0.33 \pm 0.18, n=5, \mathrm{p}<0.05)$ and $74.2 \% \pm 7.7 \%$ (+ Pyr6, change in ratio $=0.47 \pm 0.14, n=3, p<0.05$ ), respectively. The data clearly demonstrate that UTP-induced calcium influx was different from typical SOCE. To examine whether UTP can affect the Tg-sensitive calcium stores, Tg was added after the UTP-induced calcium increase returned to basal level (Fig. $7 A$ ). An increase in calcium was observed, and the ratio change of Tg-induced calcium increase was not statistically different from that of the control (in the absence of UTP; Fig. $7 B$ ). These data indicate that $5 \mu \mathrm{M}$ UTP was not sufficient to deplete the Tg-sensitive intracellular calcium stores. 
Fig. 7. UTP did not deplete the Tg-sensitive calcium stores. (A) Representative recording of Fura-2 fluorescence ratio showing the effect of $\mathrm{Tg}$ - induced calcium increase after the intracellular stores were released by UTP under $\mathrm{Ca}^{2+}$-free condition. Summarized data comparing the calcium increase induced

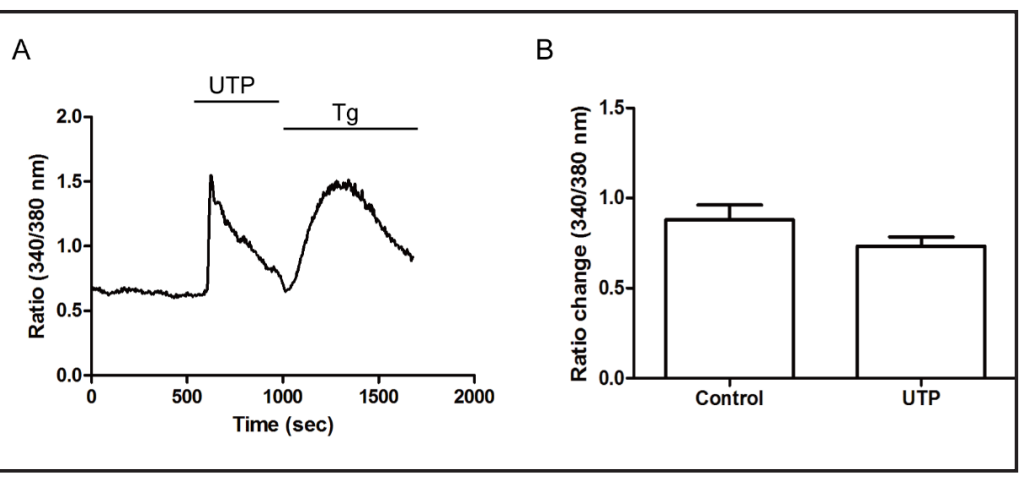
by $\mathrm{Tg}$ in the presence or absence of UTP. Each column represents the mean \pm S.E. $(n=4-6$; Student's t-test with Welch's correction).

Fig. 8. The inhibitory effect of CORM-2 on UTP-induced calcium increase was dependent on SGC/PKG pathway. (A) Representative recordings of Fura-2 fluorescence ratios showing the effects of $30 \mu \mathrm{M}$ CORM-2 (blue trace), ODQ with CORM-2 (red trace) and KT5823 with CORM-2 (green trace) on UTP-induced calcium increase. The arrow indicates where UTP was added. (B) Summarized data showing the effects of ODQ or KT5823 on the inhibitory effect of CORM-2. (C) Effect of CORM-2 on PKG activity. Each column represents the mean \pm S.E. ( $n=4-5 ;{ }^{*} p<0.05$ compared with control, one-way ANOVA with Dunnett's post hoc test).

The inhibitory effect of CORM-2 on P2Y receptormediated calcium increase was $s G C / P K G$ dependent

Carbon monoxide is known to activate the sGC/ PKG pathway [1]. Therefore, we examined whether sGC/PKG is involved in the inhibitory effect of CORM2 on P2Y receptor-mediated calcium signaling. Fig. $8 A$ shows that CORM-2 suppressed UTP-induced calcium increase significantly (blue trace). However, this inhibitory effect was attenuated by $100 \mu \mathrm{M}$ ODQ, a sGC inhibitor (red trace), or $5 \mu \mathrm{M}$ KT5823, a PKG inhibitor (green trace). In the presence of CORM2 , UTP-induced calcium increase was only $34.5 \% \pm$ $0.7 \%$ compared to that of the control, and this percentage increased to $70.6 \% \pm 6.4 \%$ and $77.5 \% \pm 7.7 \%$ when ODQ or KT5823 was present, respectively (Fig. $8 B$ ). Treatment with CORM-2 led to increased PKG activity $(1.47 \pm 0.08$ - fold $v s$. control), and this effect could be blocked by KT5823 (1.13 $\pm 0.04-$ fold $v s$. control). The CORM-2 negative control, $\mathrm{RuCl}_{3}$, had no effect on PKG activity (Fig. 8C).

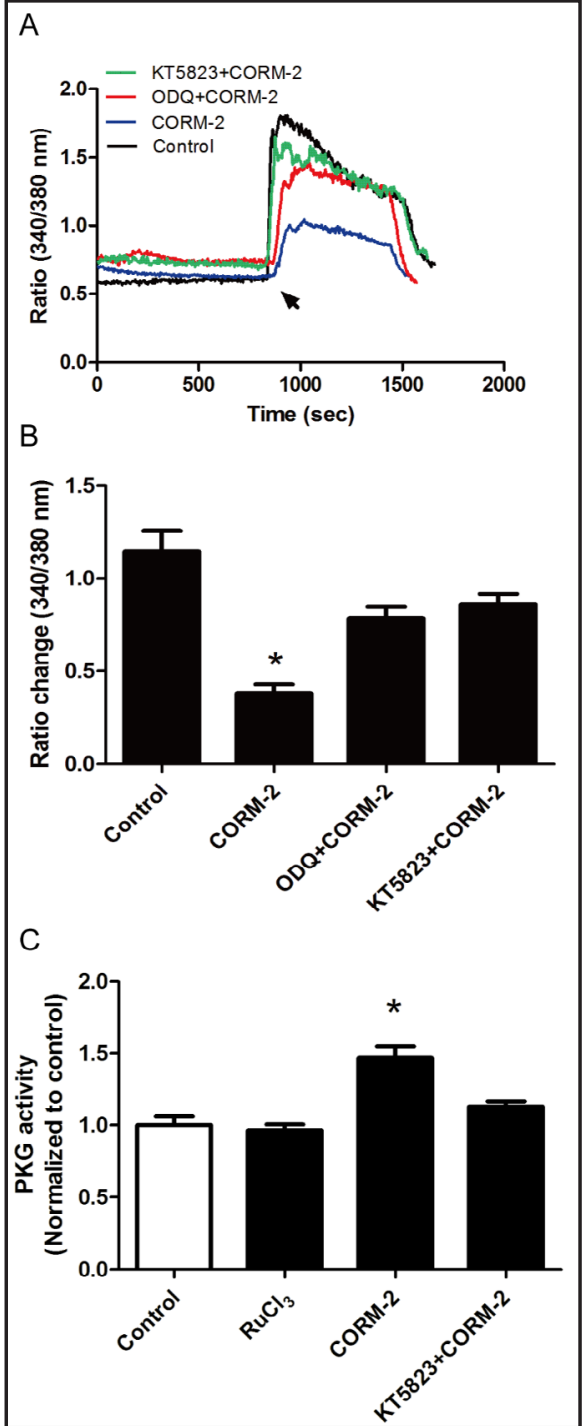

CORM-2 and UTP did not have any additive effect on $I P_{3}$ formation

Because UTP-induced calcium increase was dependent on the PLC/IP ${ }_{3}$ signaling pathway and because CORM- 2 could also induce IP formation, we examined whether UTP and CORM- 
Fig. 9. Effect of CORM-2 on UTP-induced $I_{1}$ accumulation. CORM-2 and UTP did not have any additive effect on $\mathrm{IP}_{1}$ accumulation. Each column represents the mean \pm S.E. ( $n$ =3-5; One-way ANOVA with Dunnett's post hoc test).

2 had an additive effect on the formation of $\mathrm{IP}_{1}$. Fig. 9 shows that UTP $(10 \mu \mathrm{M})$ or CORM-2 (10 $\mu \mathrm{M})$ alone, induced an increase in IP ${ }_{1}$ formation. However, in the presence of both CORM-2 (10 $\mu \mathrm{M})$ and UTP $(10 \mu \mathrm{M}), \mathrm{IP}_{1}$ formation did not differ significantly from that of UTP or CORM-2 alone. Similarly, the $\mathrm{IP}_{1}$ formation induced by CORM-2 $(100 \mu \mathrm{M})$ and UTP $(10 \mu \mathrm{M})$ was not statistically

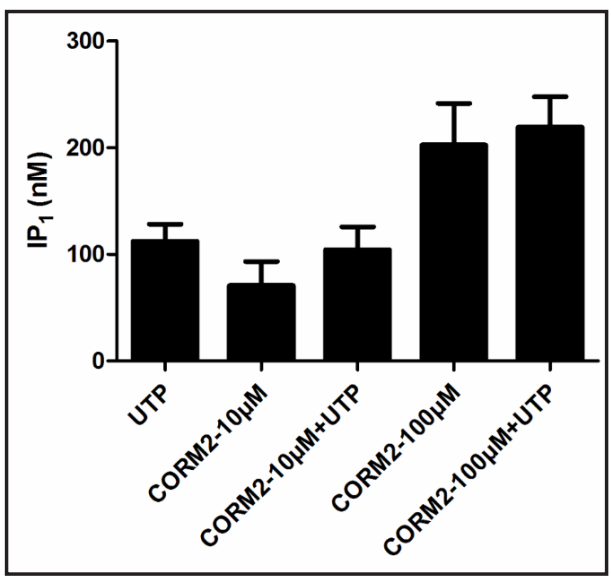
different from that of CORM-2 alone. These data suggest that there was no additive effect of the combination of both CORM-2 and UTP on IP ${ }_{1}$ formation, suggesting that CORM-2 and UTP may share a common pathway to induce $\mathrm{IP}_{3}$ formation.

\section{Discussion}

This study demonstrated, for the first time, the regulatory effect of CO released by CORM2 on calcium homeostasis in 16HBE14o- human bronchial epithelial cells. Although we did not directly measure the actual CO concentration in the solution bathing the cells, Motterlini et al. performed a series of elegant experiments to demonstrate that the CORMs, including CORM-2, rapidly liberate $\mathrm{CO}$ to elicit vasodilatory effects in rat aortic rings by measuring the conversion of deoxymyoglobin to carbonmonoxy myoglobin spectrophotometrically [12]. In this study, at higher concentrations (e.g., $100 \mu \mathrm{M}$ ), CORM-2 could induce a slow, yet long-lasting, calcium increase in human bronchial epithelial cells. This effect appeared to be dependent on the CO released by CORM-2 because iCORM-2, which did not liberate $\mathrm{CO}$, had no effect on the calcium levels. The time course is similar to what was previously observed in rat pancreatic acinar cells when 100 or $300 \mu \mathrm{M}$ of CORM-2 was applied to the cells [31]. However, in pancreatic cells, the $\left[\mathrm{Ca}^{2+}\right]_{i}$ changes were found to be oscillatory at medium concentrations $(0.4-0.5 \mathrm{mM})$ in the extracellular solution, and monophasic (1 $\mathrm{mM}$ ) at the highest concentration, which is typical of pancreatic acini cells when stimulated with physiological secretagogues such as CCK-8 or acetylcholine [31]. The fact that calcium increase induced by CORM-2 could be abolished in cells superfused with $\mathrm{Ca}^{2+}$-free $\mathrm{KH}$ solution or by pretreatment of the cells with PLC inhibitor U73122, suggests a joint participation of both intracellular calcium release and extracellular calcium entry. This is different from pancreatic cells in which the increase in $\left[\mathrm{Ca}^{2+}\right]_{i}$ was predominately due to PLC/ $\mathrm{IP}_{3}$-triggered intracellular $\mathrm{Ca}^{2+}$ mobilization [31]. CORM-2 could induce IP ${ }_{1}$ accumulation in a concentration-dependent manner, and it is interesting to note that $10 \mu \mathrm{M}$ CORM-2 almost induced the same amount of IP ${ }_{1}$ production as that of $10 \mu \mathrm{M} \mathrm{UTP}$, indicating that CO released by CORM-2 may be an effective PLC activator as compared to the activation of a G proteincoupled receptor. Because activation of the $\mathrm{PLC} / \mathrm{IP}_{3}$ pathway leads to intracellular calcium release, intracellular calcium stores of $16 \mathrm{HBE} 140$ - cells might be, at least partially, depleted upon CORM-2 treatment resulting in the activation of SOCE. Consistent with this hypothesis, both 2-APB and Pyr6 suppressed CORM-2-induced calcium increase (Fig. 1E). Pyr6 only partially suppressed the calcium influx, and the rest may be due to other calcium entry pathways, such as PLC/diacylglycerol (DAG) activated calcium influx [40, 41].

Although $100 \mu \mathrm{M}$ CORM-2 induced more IP $_{1}$ production than UTP, CORM-2 induced only a minor release of calcium in a calcium-free solution (Fig. $1 C$ and $D$ ). One possibility is that CORM-2 induced the production of $\mathrm{IP}_{3}$ in a relatively slow fashion and the newly produced 
$\mathrm{IP}_{3}$ was rapidly degraded. This is consistent with our findings of the CORM-2-induced calcium increase, in which more time was required to reach peak levels. Because the assay only allowed for the end-point measurement of $\mathrm{IP}_{1}$ accumulation within a fixed time interval, it was not possible to describe the localization and dynamic changes of $\mathrm{IP}_{3}$ levels in different subdomains within the cells. Therefore, it was not possible to correlate the changes in [IP ${ }_{1}$ to that of intracellular $\mathrm{Ca}^{2+}$ release or subsequent changes in $\left[\mathrm{Ca}^{2+}\right]_{\mathrm{i}}$. It is interesting to note that a recent report from Charles et al. demonstrated that real-time increases in $\mathrm{IP}_{3}$ levels could be monitored using confocal microscopy in HeLa cells transfected with a fusion protein made of the Pleckstrin Homology (PH) domain of PLC $\delta$ and enhanced green fluorescent protein (eGFP) [42]. The fusion protein binds to phosphatidylinositol 4, 5-bisphosphate ( $\mathrm{PIP}_{2}$ ) and $\mathrm{IP}_{3}$ and allows the monitoring of $\mathrm{IP}_{3}$ localization after $\mathrm{PIP}_{2}$ cleavage regardless of the PLC isoform [42]. Future studies involving this advanced approach will be required to unravel the underlying mechanisms.

This study also revealed an inhibitory effect of CORM-2 on P2Y receptor agonist-induced calcium signaling. As shown in Fig. 3 and 4, CORM-2 inhibited both calcium release and influx induced by UTP in a concentration-dependent manner. The inhibitory effect on calcium release was probably due to the fact that both agents share a common PLC pathway to induce $\mathrm{IP}_{3}$ formation. CORM-2 also exerted a direct inhibitory effect on UTP-induced calcium influx, which was due to SGC/PKG signaling activated by CORM-2. As shown in Fig. 8, inhibition of sGC or PKG reversed the inhibitory action of CORM-2 on UTP-induced calcium signaling. The cGMP signaling pathway is known to participate in vasodilation, which can be blocked by ODQ or KT5823 [43]. Similar to nitric oxide, CO is considered a major component in the regulation of cardiovascular circulation [44] via activation of the cGMP signaling pathway $[45,46]$. Together with these reports, our data further confirm that sGC, which localizes to the cell surface, is one of the proximal targets for CO [11].

Because the UTP-mediated $\mathrm{Ca}^{2+}$ influx was not sensitive to Pyr-6 (Fig. 6B), it is likely that CORM-2 could inhibit other calcium entry pathways, such as ROCE, which is activated by the P2Y receptor. Although it has been reported that CORM-2 inhibits L-type [47] and T-type [30] $\mathrm{Ca}^{2+}$ channels, there is currently no evidence that $16 \mathrm{HBE} 140-$ cells express these two types of voltage-gated $\mathrm{Ca}^{2+}$ channels.

The finding that the activation of SOCE by Tg was not affected by $100 \mu \mathrm{M}$ CORM-2 (Fig. 5) was unexpected. In contrast, it has been shown that $\mathrm{CO}$ inhibits the capacitative calcium entry induced by Tg in human platelets [48]. CO also inhibits the calcium influx induced by ADP and thrombin, although it was not known whether the $\mathrm{Ca}^{2+}$ entry was mediated through SOCE or ROCE [48]. On the contrary, CO released by CORM-2 enhanced the Tg-induced capacitative calcium entry in SH-SY5Y cells, a human neuroblastoma cell line, possibly by inhibiting $\mathrm{Ca}^{2+}$ extrusion via plasma membrane $\mathrm{Ca}^{2+}$-ATPase through a nitric oxide-dependent increase in reactive oxygen species [49]. Therefore, CO causes diverse modulatory effects on the calcium entry pathway and the effect is probably cell-type specific.

To demonstrate the difference between SOCE and ROCE, 2-APB and Pyr6 were used. In the present study, Pyr6 only suppressed SOCE elicited by Tg, whereas 2-APB inhibited both the Tg- and UTP- induced calcium entry (Fig. 6). Activation of P2Y receptors by UTP would also deplete intracellular calcium stores by activating $\mathrm{IP}_{3} /$ calcium signaling, leading to the activation of SOCE. However, our data suggest that $5 \mu \mathrm{M}$ UTP did not significantly deplete the Tg-sensitive calcium store, which is not sufficient to activate SOCE. As shown in Fig. 7, the ratio change of Tg-induced SOCE was not significantly different in the control cells or when the cells were previously treated with UTP. Moreover, the P2Y receptormediated calcium influx component only occurred in the continuous presence of UTP (data not shown), suggesting that store depletion alone might not be sufficient to activate calcium entry. The second possibility is that the UTP-releasable $\mathrm{Ca}^{2+}$ stores do not overlap with Tgreleasable calcium stores. Therefore, UTP was not able to activate SOCE as Tg. However, we have demonstrated previously that $10 \mu \mathrm{M}$ ATP (P2Y ${ }_{1} / \mathrm{P}_{2} \mathrm{Y}_{2}$ agonist) can stimulate the oligomerization and translocation of stromal interaction molecule 1 (STIM1) near the plasma membrane [32]. Also, $10 \mu \mathrm{M}$ ATP induced a significant increase in STIM1 puncta formation in 
16HBE140- cells [32]. Therefore, the most likely explanation is that UTP activates a calcium entry pathway that is truly distinct from SOCE. However, the detailed molecular mechanism underlying the inability of UTP to induce Pyr6-inhibitable SOCE remains unresolved.

Some studies suggest that TRP cation channels formed ROCE [50, 51]. Among the TRP channels, the TRPC family was indeed a perfect candidate to form ROCE; TRPC2, 3, 6, and 7 can be activated by DAG, a potent lipid messenger produced from PIP ${ }_{2}$ by PLC activation, and activation of TRPC4 and 5 was PLC-dependent [52]. In mouse airway epithelial cells, TRPV4 participated in ROCE instead of SOCE [27], further indicating the possible involvement of TRP channels in ROCE. However, reports on the effects of CO on TRP channels are scarce. The molecular identity of ROCE activated by UTP remains unknown and requires further investigation.

In the future, it will be important to measure the real-time changes in CO levels inside living cells in the presence of CORMs and to correlate CO levels with their biological activities, although this still remains as an ongoing challenge. It has been reported that cellular CO levels could be measured using a selective fluorescent probe [53] or a genetically-encoded fluorescent probe containing a CO-sensing heme protein from Rhodospirillum rubrum [54].

\section{Conclusion}

CORM-2 had dual effects on intracellular calcium regulation in 16HBE14o- cells. At higher concentrations, CORM-2 stimulated the $\mathrm{PLC} / \mathrm{IP}_{3} /$ calcium pathway to increase $\left[\mathrm{Ca}^{2+}\right]$ i, whereas at lower concentrations, CORM-2 inhibited calcium signaling induced by P2Y receptor agonists in an $\mathrm{SGC} / \mathrm{PKG}$-dependent manner. $\mathrm{P} 2 \mathrm{Y}$ receptor agonists stimulated the release of two important pro-inflammatory cytokines, IL-6 and IL-8, and this process was calcium-dependent [7]. Therefore, CO might exert its anti-inflammatory effect in human bronchial epithelial cells by regulating the P2Y receptor-mediated calcium-signaling pathway. Thus, $\mathrm{CO}$ might act as an important regulator of calcium homeostasis in human airway epithelia.

\section{Acknowledgements}

This work was supported by Research Grant Council General Research Fund (\#466913) awarded to W. H. Ko. We would like to thank Dr. D. C. Gruenert (Burlington, Vermont, USA) for the generous gift of 16HBE14o- cells.

\section{Disclosure Statement} article.

The authors declare that they have no conflicts of interest with the contents of this

\section{References}

1 Wu L, Wang R: Carbon monoxide: endogenous production, physiological functions, and pharmacological applications. Pharmacol Rev 2005;57:585-630.

2 Horvath I, Donnelly LE, Kiss A, Paredi P, Kharitonov SA, Barnes PJ: Raised levels of exhaled carbon monoxide are associated with an increased expression of heme oxygenase- 1 in airway macrophages in asthma: a new marker of oxidative stress. Thorax 1998;53:668-672.

3 Ryter SW, Alam J, Choi AM: Heme oxygenase-1/carbon monoxide: from basic science to therapeutic applications. Physiol Rev 2006;86:583-650.

4 Donnelly LE, Barnes PJ: Expression of heme oxygenase in human airway epithelial cells. Am J Respir Cell Mol Biol 2001;24:295-303.

5 Coburn RF, Blakemore WS, Forster RE: Endogenous carbon monoxide production in man. J Clin Invest 1963;42:1172-1178.

6 Von Burg R: Carbon monoxide. J Appl Toxicol 1999;19:379-386. 


\section{Cellular Physiology Cell Physiol Biochem 2017;42:2377-2390 \begin{tabular}{ll|l} 
and Biochemistry & $\begin{array}{l}\text { DOI: 10.1159/000480029 } \\
\text { Published online: August 18, } 2017\end{array}$ & $\begin{array}{l}\text { @ } 2017 \text { The Author(s). Published by S. Karger AG, Basel } \\
\text { www.karger.com/cpb }\end{array}$ \\
\hline
\end{tabular} \\ Zhang et al.: $\mathrm{CO}$ and Calcium Homeostasis}

7 Russell MA: Blood carboxyhaemoglobin changes during tobacco smoking. Postgrad Med J 1973;49:684687.

8 Ryter SW, Choi AM: Carbon monoxide in exhaled breath testing and therapeutics. J Breath Res 2013;7:017111.

-9 Tseng FJ, Chia WT, Wang CH, Shyu JF, Gou GH, Shui HA, Sytwu HK, Pan RY, Weng CF: Carbon Monoxide Inhibits Receptor Activator of NF-kappaB (RANKL)-Induced Osteoclastogenesis. Cell Physiol Biochem 2015;36:1250-1258.

10 Mayr FB, Spiel A, Leitner J, Marsik C, Germann P, Ullrich R, Wagner O, Jilma B: Effects of carbon monoxide inhalation during experimental endotoxemia in humans. Am J Respir Crit Care Med 2005;171:354-360.

11 Motterlini R, Otterbein LE: The therapeutic potential of carbon monoxide. Nat Rev Drug Discov 2010;9:728-743.

12 Motterlini R, Clark JE, Foresti R, Sarathchandra P, Mann BE, Green CJ: Carbon monoxide-releasing molecules: characterization of biochemical and vascular activities. Circ Res 2002;90:E17-E24.

13 Sawle P, Foresti R, Mann BE, Johnson TR, Green CJ, Motterlini R: Carbon monoxide-releasing molecules (CO-RMs) attenuate the inflammatory response elicited by lipopolysaccharide in RAW264.7 murine macrophages. Br J Pharmacol 2005;145:800-810.

14 Liu XH, Wang XL, Xin H, Wu D, Xin XM, Miao L, Zhang QY, Zhou Y, Liu Q, Zhang Q Zhu YZ: Induction of Heme Oxygenase- 1 by Sodium 9-Hydroxyltanshinone IIA Sulfonate Derivative Contributes to Inhibit LPSMediated Inflammatory Response in Macrophages. Cell Physiol Biochem 2015;36:1316-1330.

-15 Desmard M, Foresti R, Morin D, Dagouassat M, Berdeaux A, Denamur E, Crook SH, Mann BE, Scapens D, Montravers P, Boczkowski J, Motterlini R: Differential antibacterial activity against Pseudomonas aeruginosa by carbon monoxide-releasing molecules. Antioxid Redox Signal 2012;16:153-163.

16 Jacobson KA, Paoletta S, Katritch V, Wu B, Gao ZG, Zhao Q, Stevens RC, Kiselev E: Nucleotides Acting at P2Y Receptors: Connecting Structure and Function. Mol Pharmacol 2015;88:220-230.

17 Cozens AL, Yezzi MJ, Kunzelmann K, Ohrui T, Chin L, Eng K, Finkbeiner WE, Widdicombe JH, Gruenert DC: CFTR expression and chloride secretion in polarized immortal human bronchial epithelial cells. Am J Respir. Cell Mol Biol 1994;10:38-47.

18 Bernard K, Bogliolo S, Ehrenfeld J: Vasotocin and vasopressin stimulation of the chloride secretion in the human bronchial epithelial cell line, 16HBE14o-. Br J Pharmacol 2005;144:1037-1050.

19 Bernard K, Bogliolo S, Soriani 0, Ehrenfeld J: Modulation of calcium-dependent chloride secretion by basolateral SK4-like channels in a human bronchial cell line. J Membr Biol 2003;196:15-31.

20 Holgate ST, Lackie PM, Davies DE, Roche WR, Walls AF: The bronchial epithelium as a key regulator of airway inflammation and remodelling in asthma. Clin Exp Allergy 1999;29:S90-95.

-21 Kidney JC, Proud D: Neutrophil transmigration across human airway epithelial monolayers: mechanisms and dependence on electrical resistance. Am. J. Respir. Cell Mol Biol 2000;23:389-395.

22 Puddicombe SM, Polosa R, Richter A, Krishna MT, Howarth PH, Holgate ST, Davies DE: Involvement of the epidermal growth factor receptor in epithelial repair in asthma. FASEB J 2000;14:1362-1374.

23 Hao Y, Liang JF, Chow AW, Cheung WT, Ko WH: P2Y6 receptor-mediated proinflammatory signaling in human bronchial epithelia. PLoS One 2014;9:e106235.

24 Chow AW, Liang JF, Wong JS, Fu Y, Tang NL, Ko WH: Polarized secretion of interleukin (IL)-6 and IL-8 by human airway epithelia 16HBE140- cells in response to cationic polypeptide challenge. PLoS One 2010;5:e12091.

25 Clapham DE: Calcium signaling. Cell 2007;131:1047-1058. Parekh AB, Putney JW, Jr.: Store-operated calcium channels. Physiol Rev 2005;85:757-810. Lorenzo IM, Liedtke W, Sanderson MJ, Valverde MA: TRPV4 channel participates in receptor-operated calcium entry and ciliary beat frequency regulation in mouse airway epithelial cells. Proc Natl Acad Sci USA 2008;105:12611-12616.

28 Salmon MD, Ahluwalia J: Pharmacology of receptor operated calcium entry in human neutrophils. Int Immunopharmacol 2011;11:145-148.

29 Wilkinson WJ, Kemp PJ: Carbon monoxide: an emerging regulator of ion channels. J Physiol 2011;589:3055-3062.

-30 Boycott HE, Dallas ML, Elies J, Pettinger L, Boyle JP, Scragg JL, Gamper N, Peers C: Carbon monoxide inhibition of Cav3.2 T-type Ca2+ channels reveals tonic modulation by thioredoxin. FASEB J 2013;27:33953407.

-31 Moustafa A, Habara Y: A novel role for carbon monoxide as a potent regulator of intracellular Ca2+ and nitric oxide in rat pancreatic acinar cells. Am J Physiol Cell Physiol 2014;307:C1039-1049.

32 Hao Y, Chow AW, Yip WC, Li CH, Wan TF, Tong BC, Cheung KH, Chan WY, Chen Y, Cheng CH, Ko WH: G protein-coupled estrogen receptor inhibits the $\mathrm{P} 2 \mathrm{Y}$ receptor-mediated $\mathrm{Ca}^{2+}$ signaling pathway in human airway epithelia. Pflugers Arch 2016;468:1489-1503. 


\section{Cellular Physiology Cell Physiol Biochem 2017;42:2377-2390

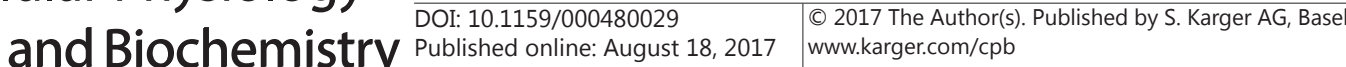

Zhang et al.: $\mathrm{CO}$ and Calcium Homeostasis

-33 Hiemstra JA, Lee DI, Chakir K, Gutierrez-Aguilar M, Marshall KD, Zgoda PJ, Cruz Rivera N, Dozier DG, Ferguson BS, Heublein DM, Burnett JC, Scherf C, Ivey JR, Minervini G, McDonald KS, Baines CP, Krenz M, Domeier TL, Emter CA: Saxagliptin and Tadalafil Differentially Alter Cyclic Guanosine Monophosphate (cGMP) Signaling and Left Ventricular Function in Aortic-Banded Mini-Swine. J Am Heart Assoc 2016;5:e003277.

-34 Schleifer H, Doleschal B, Lichtenegger M, Oppenrieder R, Derler I, Frischauf I, Glasnov TN, Kappe CO, Romanin C, Groschner K: Novel pyrazole compounds for pharmacological discrimination between receptor-operated and store-operated Ca(2+) entry pathways. Br J Pharmacol 2012;167:1712-1722.

35 Bootman MD, Collins TJ, Mackenzie L, Roderick HL, Berridge MJ, Peppiatt CM: 2-aminoethoxydiphenyl borate (2-APB) is a reliable blocker of store-operated Ca2 + entry but an inconsistent inhibitor of InsP3induced Ca2+ release. FASEB J 2002;16:1145-1150.

-36 Bencze M, Behuliak M, Vavrinova A, Zicha J: Broad-range TRP channel inhibitors (2-APB, flufenamic acid, SKF-96365) affect differently contraction of resistance and conduit femoral arteries of rat. Eur J Pharmacol 2015;765:533-540.

-37 Maruyama T, Kanaji T, Nakade S, Kanno T, Mikoshiba K: 2APB, 2-aminoethoxydiphenyl borate, a membranepenetrable modulator of Ins(1, 4,5)P3-induced Ca2+ release. J Biochem 1997;122:498-505.

38 Wong $\mathrm{CH}$, Ko WH: Stimulation of $\mathrm{Cl}^{-}$secretion via membrane-restricted $\mathrm{Ca}^{2+}$ signaling mediated by P2Y receptors in polarized epithelia. J Biol Chem 2002;277:9016-9021.

-39 Thastrup 0, Cullen PJ, Drobak BK, Hanley MR, Dawson AP: Thapsigargin, a tumour promoter, discharges intracellular calcium stores by specific inhibition of the endoplasmic reticulum $\mathrm{Ca}^{2+}$ TPase. Proc Nat Acad Sci USA 1990;87:2466?2470.

40 May V, Clason TA, Buttolph TR, Girard BM, Parsons RL: Calcium influx, but not intracellular calcium release, supports PACAP-mediated ERK activation in HEK PAC1 receptor cells. J Mol Neurosci 2014;54:342-350.

41 Pulcinelli FM, Trifiro E, Massimi I, Di Renzo L: A functional interaction between TRPC/NCKX induced by DAG plays a role in determining calcium influx independently from PKC activation. Platelets 2013;24:554559.

42 Charles E, Hammadi M, Kischel P, Delcroix V, Demaurex N, Castelbou C, Vacher AM, Devin A, Ducret T, Nunes P, Vacher P: The antidepressant fluoxetine induces necrosis by energy depletion and mitochondrial calcium overload. Oncotarget 2017;8:3181-3196.

43 Li RW, Yang C, Chan SW, Hoi MP, Lee SM, Kwan YW, Leung GP: Relaxation effect of abacavir on rat basilar arteries. PLoS One 2015;10:e0123043.

44 Leffler CW, Fedinec AL, Parfenova H, Jaggar JH: Permissive contributions of NO and prostacyclin in COinduced cerebrovascular dilation in piglets. Am J Physiol Heart Circ Physiol 2005;289:H432-438.

45 Motterlini R, Sawle P, Hammad J, Bains S, Alberto R, Foresti R, Green CJ: CORM-A1: a new pharmacologically active carbon monoxide-releasing molecule. FASEB J 2005;19:284-286.

-46 Foresti R, Hammad J, Clark JE, Johnson TR, Mann BE, Friebe A, Green CJ, Motterlini R: Vasoactive properties of CORM-3, a novel water-soluble carbon monoxide-releasing molecule. Br J Pharmacol 2004;142:453-460.

47 Dallas ML, Scragg JL, Peers C: Inhibition of L-type Ca(2+) channels by carbon monoxide. Adv Exp Med Biol 2009;648:89-95.

48 Gende OA: Carbon monoxide inhibits capacitative calcium entry in human platelets. Thromb Res 2004;114:113-119.

49 Hettiarachchi NT, Boyle JP, Bauer CC, Dallas ML, Pearson HA, Hara S, Gamper N, Peers C: Peroxynitrite mediates disruption of $\mathrm{Ca} 2+$ homeostasis by carbon monoxide via Ca2+ ATPase degradation. Antioxid Redox Signal 2012;17:744-755.

50 Chow JY, Estrema C, Orneles T, Dong X, Barrett KE, Dong H: Calcium-sensing receptor modulates extracellular $\mathrm{Ca}(2+)$ entry via TRPC-encoded receptor-operated channels in human aortic smooth muscle cells. Am J Physiol Cell Physiol 2011;301:C461-468.

-51 Peng G, Li S, Hong W, Hu J, Jiang Y, Hu G, Zou Y, Zhou Y, Xu J, Ran P: Chronic Hypoxia Increases Intracellular $\mathrm{Ca}(2+)$ Concentration via Enhanced $\mathrm{Ca}(2+)$ Entry Through Receptor-Operated $\mathrm{Ca}(2+)$ Channels in Pulmonary Venous Smooth Muscle Cells. Circ J 2015;79:2058-2068.

-52 Mori MX, Itsuki K, Hase H, Sawamura S, Kurokawa T, Mori Y, Inoue R: Dynamics of receptor-operated $\mathrm{Ca}(2+)$ currents through TRPC channels controlled via the PI(4, 5)P2-PLC signaling pathway. Front Pharmacol 2015;6:22.

53 Michel BW, Lippert AR, Chang CJ: A reaction-based fluorescent probe for selective imaging of carbon monoxide in living cells using a palladium-mediated carbonylation. J Am Chem Soc 2012;134:1566815671.

-54 Wang J, Karpus J, Zhao BS, Luo Z, Chen PR, He C: A selective fluorescent probe for carbon monoxide imaging in living cells. Angew Chem Int Ed Engl 2012;51:9652-9656. 